\title{
Experience of family members providing care for HIV-exposed children: beginning of the trajectory
}

\author{
Experiência de familiares no cuidado à criança \\ exposta ao HIV: o início da trajetória
}

Experiencia de familiares en el cuidado de niños

expuestos al VIH: comenzando la trayectoria

\author{
Willyane de Andrade Alvarenga ${ }^{a}$ \\ Mariana Ramos da Silvab \\ Lucila Castanheira Nascimentoc \\ Monika Wernet $^{d}$ \\ Fernanda Ferreira Damaceno Oliveira ${ }^{e}$ \\ Giselle Dupas ${ }^{f}$
}

\begin{abstract}
During and after pregnancy, mothers with HIV can undergo treatment that is capable of preventing vertical transmission (VT) to their babies. The purpose of this study was to analyze the experience of family members that provide care for children whose mothers have HIV, to reduce the risk of VT, with emphasis on the beginning of this trajectory. This study was based on the qualitative approach and Symbolic Interactionism was adopted as a theoretical framework. A total of 36 family members participated in the study, all of whom were carers of children aged up to 18 months and waiting for confirmation of the HIV diagnosis. Data were collected in a hospital in north-eastern Brazil, between December 2012 and February 2013, and examined by means of content analysis. Child care began during pregnancy, when the possibility of the child having HIV was expected. Some had previous experience in providing care for exposed children. Understanding the early trajectory of care will help find ways to provide better support for carers during the trajectory of diagnosis confirmation.
\end{abstract}

Descriptors: HIV. Infectious disease transmission, vertical. Pregnancy. Child care. Paediatric nursing.

\section{RESUMO}

Durante e após a gestação, há cuidados capazes de prevenir a transmissão vertical (TV) do HIV. Objetivou-se analisar a experiência de familiares no cuidado à criança filha de mãe com HIV para reduzir o risco de TV, com ênfase no início dessa trajetória. Utilizaram-se abordagem qualitativa e o Interacionismo Simbólico como referencial teórico. Foram entrevistados 36 familiares cuidadores de criança com idade de até 18 meses, com diagnóstico de HIV a confirmar. Os dados foram coletados num hospital do Nordeste do Brasil, entre dezembro de 2012 e fevereiro de 2013, e examinados através da análise de conteúdo. 0 cuidado à criança se iniciou durante a gravidez, quando imagina-se a possibilidade dela ter HIV. Alguns cuidadores tinham experiência anterior de cuidado à criança exposta. Compreender esse início do cuidado possibilitará melhor apoiar os cuidadores ao longo da trajetória de confirmação do diagnóstico da criança. Descritores: HIV. Transmissão vertical de doença infecciosa. Gravidez. Cuidado da criança. Enfermagem pediátrica.

\section{RESUMEN}

Durante y después del embarazo, hay cuidados capaces de prevenir la transmisión vertical (TV) del VIH. El objetivo fue analizar la experiencia de familiares con relación al cuidado de niños hijos de madres con VIH para reducir el riesgo de TV, con énfasis en el comienzo de esta trayectoria. Se utilizó un enfoque cualitativo y el Interaccionismo Simbólico como marco teórico. 36 cuidadores familiares de niños de hasta 18 meses y con el diagnóstico para confirmar fueron entrevistados. Los datos fueron recogidos en un hospital en el noreste de Brasil, entre diciembre de 2012 y febrero 2013, y se examinaron mediante análisis de contenido. El cuidado de niños se inició durante el embarazo, durante el cual, se imagina la posibilidad de que tenga VIH. Algunos tenían experiencia previa en el cuidado de niños expuestos. La comprensión del principio de la trayectoria del cuidado infantil permitirá encontrar maneras para mejor ayudar a los cuidadores a lo largo de la trayectoria de la confirmación del diagnóstico.

Descriptores: VIH. Transmisión vertical de enfermedad infecciosa. Embarazo. Cuidado del niño. Enfermería pediátrica.
D0l: $\quad$ http://dx.doi.org/10.1590/19831447.2014.03.43938

\footnotetext{
Master's degree in Nursing. Doctoral degree student in Public Health, School of Nursing of Ribeirão Preto, Universidade de São Paulo, WHO Collaborating Centre for Nursing Research Development, São Paulo, Brazil.

${ }^{b}$ Degree student in Nursing, Universidade Federal de São Carlos. São Carlos, SP, Brazil.

(PhD in Nursing, Associate Professor, School of Nursing of Ribeirão Preto, Universidade de São Paulo, WHO Collaborating Centre for Nursing Research Development, São Paulo, Brazil.

d PhD in Nursing, Associate Professor, Department of Nursing, Universidade Federal de São Carlos. São Carlos, São Paulo, Brazil.

' Master's degree in Nursing from Universidade Federal de São Carlos. São Carlos, São Paulo, Brazil.

f PhD in Nursing, Associate Professor, Department of Nursing, Universidade Federal de São Carlos. São Carlos, São Paulo, Brazil.
} 


\section{口INTRODUCTION}

In Brazil, vertical transmission (VT) is the main cause of HIV infection in children under the age of $13^{(1)}$. There are nationally established measures during and after pregnancy that can reduce the possibility of HIV transmission from mother to child ${ }^{(2)}$.

In the exercise of maternity, a pregnant mother with HIV completes a long trajectory to ensure the sero-negativity of her child and, during pregnancy, she focuses on self-care and drug therapy to protect her child from VT. Fear of transmitting the virus to the child is very present and causes despair ${ }^{(3)}$. Pregnancy with HIV sero-positivity is characterized as a moment of apprehension in relation to contaminating the child ${ }^{(3-4)}$. This apprehension lasts until the child's diagnosis results and the mother must also deal with the uncertainty, guilt and demands during care to prevent $\mathrm{VT}{ }^{(5-6)}$.

In addition to the demands of being a mother with HIV, discovering the infection usually affects the individual's social network and, in the family context, determines approximation or distancing of family members due to the stigma of this disease ${ }^{(7)}$. Social support and family relationships are important resources in the experience of living with HIV and have proved powerful in improving the quality of life of people who live with the virus ${ }^{(5,8)}$. HIV directly affects the lives of infected individuals and their families and the process of interacting and caring for the child, especially the parents, but it also involves other individuals ${ }^{(9)}$. However, few studies have approached the subject of families affected by $H I V^{(8,10)}$ and, primarily, the care provided by families for exposed children. There is, therefore, the need to expand the focus of this disease or how it is understood by family members who are active, interact and adapt to the condition of living with $\mathrm{HIV}^{(9)}$.

There are recommendations of extending scientific explorations on the subjectivity of the experience of living with $\mathrm{HIV}^{(11)}$. Most studies have investigated the perception of mothers ${ }^{(3-5,7-8,12-13)}$ on subjects related to pregnancy, being a mother with HIV and breastfeeding, although it should also be considered that the experience of HIV/AIDS is not limited to those who are infected with the virus, but also to those who live with and assume the role of carers of children.

This study acknowledges the importance of professional support for the family who experiences HIV and the post-natal preventive treatment for children. It is therefore important to understand from which moment these family members consider they are providing care for children and how they experience this initial stage. In light of the ques- tion, 'how do mothers with HIV and/or carers experience the start of care for HIV-exposed children, the aim of this paper is to analyse the experience of family members who are providing care for children whose mothers are infected with HIV to reduce the risk of VT, with emphasis on the beginning of this trajectory.

\section{METHODOLOGY}

This research is based on a larger study ${ }^{(14)}$ on care for HIV-exposed children, in which the qualitative descriptive approach was used and Symbolic Interactionism was adopted as the theoretical framework. The nature of this framework basically comprises three premises: man acts according to the meaning things have for him, including everything he could perceive in his surroundings; the meaning of these things is derived from interaction with others; and meanings are manipulated and modified through interpretative processes used by individuals to deal with things they encounter ${ }^{(15)}$.

Data were collected in a hospital-school, founded in the 70s and maintained with recourses from the Unified Health System (SUS), in north-eastern Brazil, and considered a benchmark in care, prevention and treatment of patients with HIV/AIDS and exposed children both in the state and in the municipalities of neighbouring states.

Collection occurred from December 2012 to February 2013. A total of 24 mothers, five fathers and seven carers (grandparents, aunts and great grandparents) participated in the study, totalling 36 family members of children born from mothers with HIV. To be selected, participants had to be carers and have children under 18 months, without a fully defined diagnosis of HIV and receiving care at the referred service. Exclusion criteria were carers under the age of 18, and lack of knowledge on the HIV serological condition of the mother and on vertical exposure of the child. The number of participants was not pre-defined and collection was interrupted due to theoretical saturation of data, that is, when new data were no longer introduced during the interviews and the purpose of the study was achieved, assuring a full understanding of the phenomenon ${ }^{(16)}$.

Persons responsible for caring for the child and for accompanying care at the healthcare service were approached in the waiting room prior to the child's appointment and invited to a private room. In this room, all the objectives and the data collection strategy were explained to carers using an Informed Consent Form (ICF), and confidentiality and secrecy of their statements was guaranteed. Those who agreed to participate in the study signed the 
ICF. Mothers who agreed to participate and were accompanied by another family member of the child (father, grandmother or aunt) almost always asked if these members could participate in the interview. They were also carers and were aware of the child's condition, so they were included in the research and asked to sign an ICF.

Data were collected by means of semi-structured recorded interviews in a single encounter of approximately 50 minutes. The interviews were collective when other family members were present, or individual, conducted by the first author who asked the following guiding questions: "How have you experienced care to prevent the transmission of HIV to the child? Tell me when it all began and how you have experienced this process."

Data were examined according to inductive content analysis that consists of preparing, organizing and reporting results (17). The first steps of analysis, referent to the preparation stage, consisted of collecting, transcribing and reading data to get the overall sense of everything and subsequently select units of analysis and meaning. In the following stage, called organization, the inductive path resulted in coding and creating categories that were grouped to formulate a general description of the phenomenon. In the last stage, results based on contents of the categories were reported, describing the phenomenon from a historical line of events. This study describes the beginning of this time line, which is the start of the child care trajectory.

To protect the identity of participants, they were identified according to their position in relation to the child (mother, father, grandmother, aunt), followed by the number of the order in which they entered the study. To guarantee reliability, authentic statements of the participants were used to show how the categories were formulated; however, some statements were not listed because they did not specifically contribute to the time frame of this study, but were fundamental to obtain an understanding and delimitation of the child care trajectory.

This research was approved by the Human Research Ethics Committee of the Universidade Federal de São Carlos (n० 112.500/2012), and the requirements of Resolution CNS196 de 1996, in force during preparation and execution of the research project, were observed.

\section{RESULTS AND DISCUSSION}

This study reveals the beginning of the care trajectory of HIV-exposed children, from pregnancy to birth. The categories: "Imagining the child with HIV", "Having previous experience" and "Wanting the child, in spite of everything" portray the experience and are defined below.

\section{Imagining the child with HIV}

Imagining oneself with a child with HIV triggers emotions, especially guilt, in the mother and family members involved in taking care of the child because they feel responsible or incapable of doing anything to change the outcome: having a child that runs the risk of being infected.

It's really tough! I am always worried about him, with the baby. I'm always thinking, afraid he might have HIV, of giving it to him (Mother1).

I was really upset when we found out she [granddaughter] has the disease. So many things came to mind. I thought, if she [granddaughter] were with me, if she lived with me, none of this would be happening to her [great granddaughter] (Great grandmother 24).

Self-guilt is a way of confronting the situation ${ }^{(5)}$. According to Symbolic Interactionism, reality is imposed on us from the moment in which we interpret it. It is precisely continuous social interaction that interferes in the meaning of things and in human action ${ }^{(15)}$. The presence of the virus is reflected in the experience of the carer and lays the foundation for the fear and guilt of having a child with HIV. In spite of advancements in treatment, studies show that the positive diagnosis of this disease creates suffering in the individual and family members ${ }^{(8-9)}$, as it is related to the loss of identity, death, isolation and the impossibility of social interaction, which ultimately becomes a part of the daily lives of families and children ${ }^{\left({ }^{(9)}\right.}$.

Other family members also blamed themselves for the risk to which the child was exposed and, especially, for the fact that the mother acquired HIV, as if the family environment was associated to containing the infection, which shows that the family is also affected by the disease. Studies reveal that the family experiences feelings of disarray, uncertainty, guilt and impotence that are generally transformed into a reorganization, based on knowledge of the disease ${ }^{(9-10)}$.

When sero-positivity is discovered, before and during pregnancy, the possibility of transferring HIV to the child arises, which generates, in addition to guilt, fear, concern and suffering, often experienced with drug use, thoughts of death and despair. These same feelings and uncertainties related to the possibility of transmitting the virus to the child were also the results found in other studies ${ }^{(3,18)}$.

To forget, I drank a lot, went out, refused to speak. I thought about being punished, about him not being born healthy; 
because I did this and did not protect myself. I wanted to take my own life (Father26). He [husband] drank a lot when I was pregnant, because he thought something would happen to the baby (Mother26).

My companion got so upset when he saw the state I was in that he started to use "powder" [drugs]. After some time, I noticed and talked to him about why that was happening. 'Because I found out you had the virus and I didn't', he said. That's what hurt the most. He was blaming himself because I had HIV and because his son could also have it and he didn't (Mother25).

In the experience of paternity with or without sero-positivity, there were differences in relation to feelings of guilt. The father with HIV felt guilty and responsible for the birth of an HIV-exposed child, while sero-negative fathers felt guilty because they did not have HIV, for 'not sharing' the suffering of having the same diagnosis, and for the risk to which the child was exposed.

Research ${ }^{(8)}$ conducted on individuals with HIV and their sero-negative family members revealed that people who live with the virus present a greater number of depressive symptoms. In spite of the stress caused by the disease, individuals with HIV are more susceptible to psychological disorders ${ }^{(8)}$.

Faced with this diagnosis and the possibility of contaminating the child, thoughts of ending one's own life emerged and were equally found in other studies ${ }^{(4,17)}$. Drug use was also found in another study, which showed that this problem is more common in people with $\mathrm{HIV}^{(12)}$. In the United States, the key risk factors of families affected by HIV are: drug abuse, mental health and parental challenges ${ }^{(10)}$.

\section{Having previous experience}

Some participants had already taken care of HIV-exposed children; having previous experience triggered negative or positive feelings that affected confrontation of the new situation. According to the adopted theoretical framework ${ }^{(15)}$, this occurs because our past enters our actions and we think about it to define the present situation, although the cause of the action is unfolding in the present.

Familiarity with the treatment, time passed since discovery of the HIV diagnosis, successful treatment of the previous child resulting in sero-positivity, are aspects that positively affect care of the studied child in the sense of bringing tranquillity and confidence. Statements showed that stress, fear and lack of knowledge were more evident when providing care for the first HIV-exposed child.
With this one [second exposed child], I'm a lot calmer. Now, with the other one [first exposed child], I was really worried because I didn't know what to do; I didn't know I had HIV. I only found out when I got pregnant. [...] But with my second pregnancy, I did the full treatment. He was planned (Mother28).

Taking care of him is a lot easier because I already knew what I had. I had already finished all the treatment during my first pregnancy. I'm a lot more confident now. But with the first [child], it was very stressful (Mother26).

A study shows that having or not having previous experiences of maternity with exposed children does not seem to reduce anxiety in relation to the HIV diagnosis of the child(6). However, mothers who discovered their serology when pregnant with the first child more clearly expressed fear of infection due to the more recent impact of discovering they had the disease and because they still did not have a lot of information on the disease and its treatment ${ }^{(6)}$.

When women are aware of their diagnosis and have already experienced pregnancy while infected with the virus, this moment seems less intense, as past experiences showed them that after completing preventive treatment their children can be born healthy ${ }^{(18)}$. This increases the confidence of these mothers in relation to taking care of another HIV-exposed child, considering they will receive free prophylaxis during pregnancy, birth and breastfeeding, and can subsequently reduce the VT rate to less than $1 \%{ }^{(2)}$.

In contrast, apprehension in relation to the diagnosis and the risk of having yet another child with HIV are present, although increased when results of the first child are sero-positive. Feelings of guilt are sometimes relived in the new experience and considered a divine punishment for having, once again, exposed another child to HIV.

I felt bad, and still do to this day. During prenatal care, I refused to do the HIV test. I feel guilty, if I hadn't refused, I wouldn't have a child with that problem today. It's different with her, though. I did my prenatal like I was supposed to (Mother27).

I think about divine punishment. The girl [previous child] was lucky, the test was negative; now, there's the boy, who wasn't planned. We should have stopped with the girl and taken care of her. We made a mistake, and she [wife] got pregnant [...]. We'd already gotten rid of that 'burden' because we found out she [previous child] didn't have it [HIV]. Now, we found out she's pregnant. It's like a punishment. I'Il 
get my punishment with this child, because I did lots of bad things in the past (Father26).

The mother felt responsible for transmitting the virus to the child and blamed herself for getting pregnant again or for not having completed prophylactic treatment of the previous child. When this occurs, blame of other people and shame, pain and anguish are also present ${ }^{(5)}$. The belief that HIV is a punishment from God and related to bad actions from the past were also mentioned in another study (19), which stated that this may appear with feelings of rage, guilt and the desire to take one's own life.

A new pregnancy forces the family to relive feelings of fear, guilt and sadness that seemed forgotten after discovering the sero-negativity of the previous child. This is because pregnancy triggers the constant reminder of the diagnosis, which causes anxiety and concern about the serology of the child. This is a negative interaction with the disease that results in despair due to the suffering caused by the result they will obtain from the child, due to the stigma of living with the virus and the perceived risk of disease or death ${ }^{(3)}$.

\section{Wanting the child in spite of everything}

In spite of the presence of HIV, from the moment of discovery and the risk of $\mathrm{VT}$, the child was considered desired in all situations, even when unplanned or when the child was the second case of vertical exposure in the family.

My dream was to have a child and God gave one to me [...]. She was planned. [...] Sometimes, I can't believe I have her (Mother16).

My daughter was planned, we did the entire programme because my husband is sero-negative. If you ask me, she is a Godsend. Every day I spend with her is a day of victory (Mother27).

When I found out about the problem, I said, "My God, I can't have kids, I want a baby so badly!". As time passed, I realized it didn't have to be that way! [...] That's when I talked to my husband: It's time, let's have a baby! I completed the treatment correctly, the prenatal; I took the medication, never missed an appointment. I did it all, certain that he would be born without problems (Mother9).

I don't feel any rejection. As soon as I found out I was pregnant and had the disease, I thought: I'm going to do everything in my power to make sure he is born healthy. Every- thing I can do for him, I'll do. Whatever is within my reach, I'll do, because he isn't to blame (Mother25).

The statements showed that the presence of HIV did not negatively interfere with maternity and the bond with the child. This was also reported in an investigation that compared foetal maternal attachment of pregnant women with HIV and pregnant women that were not infected with the virus; and results showed that the presence of HIV did not negatively affect the mother-child relationship ${ }^{(13)}$.

The birth of a child, whether planned or not, brings joy to the environment, especially for the mother. In spite of the HIV diagnosis, a study shows that, in general, maternity is an inherent desire of women or a way of continuing their own lives that was interrupted by the virus ${ }^{(4)}$. Consequently, they try to complete VT preventive treatment with the hope of ensuring a healthy life for their children ${ }^{(3)}$. Planning to have children was also reported in another study ${ }^{(4)}$.

In this study, some mothers did not plan their pregnancies. This leads to the doubt as to whether family planning is being discussed with people with HIV. The concept of family planning in healthcare policies, that consists of presenting actions with the purpose of helping individuals with conception or preventing unwanted pregnancies, is still a challenge ${ }^{(2)}$.

When they discovered they were pregnant, the mothers did everything in their power to prevent transmission, as the child was considered a victim of the situation. The child was welcome amidst the suffering caused by the presence of HIV and difficulties experienced during treatment.

She is a victory. The girl's great grandmother says: "that little girl is a 'sweetheart' that was born. If it weren't for her [baby girl], we would've lost my granddaughter [wife]". Because a friend of ours, when he found out [he had HIV], he soon died. If it weren't for the child, maybe, when we found out, we would've died (Father3).

Statements showed that the child is viewed as a possibility to recover the lives of the parents, as its arrival allowed the parents to know their serological condition, providing them with the opportunity to take care of themselves and initiate the baby's treatment.

This aspect was also found in a study ${ }^{(3)}$, in which discovering about the pregnancy was related to the chance to discover the sero-positivity. The desire to understand the experience of suffering influenced the process, the results of becoming sick and of confronting the situation ${ }^{(20)}$.

In this study, discovering HIV was given a new meaning with the arrival of child, who was the source of 
strength, joy and the main motive for confronting the disease. In this study, the mother found motives to complete prenatal care and follow all the recommendations of the healthcare professionals, who appeared at this time to orient and give hope that it was possible to prevent infection of the child.

In relation to the child, I was very happy; She gave me strength. I was desperate, I cried all the time. Then I stopped to think about her. Now, my sole concern was the fear of transmitting it to her; That's why I did everything by the book [...]. The doctor said: "If you complete the treatment correctly, there are only two risks: breastfeeding and the moment of birth. That's why you have to do it right, so you don't run that risk". (Mother3).

I didn't kill myself because I thought about him first [child], but it was tough, it was difficult! (Mother25).

Today, I try to be strong. He gave me strength, something to be happy about, but I still get a little depressed (Father26).

Moved by the hope of no VT, the mother did everything in her power to prevent transmission to the child and minimize the guilt that it would produce. Maternal commitment with care to prevent contamination to the child is similar to findings of other studies ${ }^{(3,13,18)}$, in which women initiated drug therapy as soon as possible and attended all prenatal appointments to reduce the probability of VT. They received information that if treatment was completed correctly, the probability of a sero-negative child was greater ${ }^{(3,18)}$. The recommendation is for women to initiate the VT prophylaxis treatment between the $14^{\text {th }}$ and $28^{\text {th }}$ week of pregnancy ${ }^{(2)}$, with emphasis on the importance of completing prenatal care and incentives of the women's healthcare professional for these preventive measures to be effective.

Healthcare services value the birth of healthy babies and that reinforces the mother's decision to take care of herself, in the hope of preventing VT. Moreover, perception of the child's innocence, as not deserving this condition, and not wanting the child to experience the stigma of HIV is also evident ${ }^{(3)}$. Focusing on the child at this moment, and the possibility of the child not having HIV represents, from the interactionist standpoint, the idea that individuals know what they are doing and interpret the meanings of their own acts and the reaction that their actions have on others, which, in this case, is the child. Consequently, the reactions of others are used to control their own behaviour ${ }^{(15)}$.

\section{GINAL CONSIDERATIONS}

It was possible to learn how mothers with HIV and/ or carers experienced the start of care for HIV-exposed children. The care experience began with the mother's struggle to prevent transmission of the virus during pregnancy. This beginning was intense and there was a re/organization of the disease and pregnancy. Several emotions emerge or were relived during this experience, especially when there was another birth of an HIV-exposed child in the family. Results revealed a commitment with treatment, love and dedication of the mother/carer in relation to the child, conceived as a source of joy and life for the family.

Study limitations are the data collection strategy, completed in a single encounter and during the child's appointment. Collection at a different time to that of the appointment and with other members of the family involved in the child's care, who are aware of the mother's diagnosis, could enhance apprehension of the study object.

As implications for future research, we suggest the inclusion of other family members and the home context of care as potential aspects to expand the body of knowledge of Nursing/Healthcare and the phenomenon of living with HIV and the risks involved.

Understanding the care trajectory of these children can create awareness in healthcare professionals, especially nurs$\mathrm{es}$, in relation to needs of their mothers and families. Obtaining a deeper understanding and clarity of this process of experiencing the start of child care can reduce the risk of $\mathrm{VT}$, as it would enable us, also, to discover paths that help with the difficulties and the implementation of preventive treatment during the entire trajectory of diagnosis confirmation.

\section{REFERENCES}

1. Ministério da Saúde (BR). Boletim epidemiológico AIDS e DST. 2013; Ano II(1).

2. Ministério da Saúde (BR). Protocolo clínico e diretrizes terapêuticas para manejo da infecção pelo HIV em crianças e adolescentes. Brasília (DF); 2014.

3. Oliveira FFD, Wernet M, Silveira A0, Dupas G, Alvarenga WA. Esperança da gestante soropositiva para o vírus da imunodeficiência humana. Cienc Cuid Saúde. 2012 out-dez;11(4):730-8.

4. Galvão MTG, Cunha GH, Machado MMT. Dilemas e conflitos de ser mãe na vigência do HIV/aids. Rev Bras Enferm. 2010 maio-jun;63(3):371-6.

5. Galvão MTG, Lima ICV, Cunha GH, Mindêllo MIA. Estratégias de mães com filhos portadores de HIV para conviverem com a doença. Cogitare Enferm. 2013 abr-jun; 18(2):230-7

6. Goncalves TR, Piccinini CA. Experiencia da maternidade no contexto do HIV/aids aos três meses de vida do bebe. Psicol Teor Pesqui. 2008;24(4):459-70.

7. Padoin SMM, Souza IEO, Paula CC. Cotidianidade da mulher que tem HIV/aids: modo de ser diante da (im)possibilidade de amamentar. Rev Gaúcha Enferm. 2010 mar;31(1):77-83. 
8. Li L, Liang LJ, Ding YY, Ji G. Facing HIV as a family: predicting depressive symptoms with correlated responses. J Fam Psychol. 2011 Apr;25(2):202-9.

9. Freitas HMB, Backes DS, Pereira ADA, Ferreira CLL, Souza MHT, Marchiori MRCT et al. Understanding the family member of a child affected by human immunodeficiency virus/acquired immunodeficiency syndrome, from the perspective of complexity. Acta Paul Enferm. 2010;23(5):597-602.

10. Rotheram-Borus MJ, Swendeman D, Lee SJ, Li L, Amani B, Nartey M. Interventions for families affected by HIV. Transl Behav Med. 2011 jun;1(2):31326.

11. Botti ML, Waidman MAP, Marcon SS, Scochi MJ. Feelings and conflicts of women living with HIV/aids: a literature research. Rev Esc Enferm USP. 2009 mar; $43(1): 79-86$.

12. Santos NJS, Barbosa RM, Pinho AA, Villela WV, Aidar T, Filipe EMV. Contextos de vulnerabilidade para o HIV entre mulheres brasileiras. Cad. Saúde Pública 2009;25(Suppl2): s321-33.

13. Faria ER, Gonçalves TR, Carvalho FT, Ruschel PP, Lopes RCS, Piccinini CA. Apego materno fetal em gestantes que vivem com HIV/aids. Estud Psicol. 2013 abr-jun;18(2):231-9.
14. Alvarenga WA. Cuidar da criança exposta ao vírus da imunodeficiência humana: uma leitura à luz do interacionismo simbólico [dissertação]. São Carlos (SP): Departamento de Enfermagem, Universidade Federal de São Carlos; 2014.

15. Blumer H. Symbolic interacionism: perspective e method. Berkeley: University of California; 1986.

16. Fontanella BJB, Magdaleno Júnior R. Saturação teórica em pesquisas qualitativas: contribuições psicanalíticas. Psicol Estud. 2012;17(1):63-71

17. Elo S, Kyngäs H. The qualitative content analysis process. J Adv Nurs. 2008;62(1):107-15

18. Leal AF, Roese A, Souza AS. Medidas de prevención de la transmisión vertical del VIH empleadas por madres del ninõs seropositivos. Invest Educ Enferm. 2012 mar;30(1):44-54

19. Lyon ME, Garvie PA, Kao E, Briggs L, He J, Malow R et al. Spirituality in HIV-infected adolescents and their families: family centered (FACE) advance care planning and medication adherence. J Adolesc Health. 2011 jun;48(6):633-6.

20. Caixeta CRCB, Nascimento LC, Pedro ICS, Rocha SMM. Spiritual support for people living with HIV/aids: a Brazilian explorative, descriptive study. Nurs Health Sci. 2012;14:514-9.

\section{Author's address:}

Willyane de Andrade Alvarenga

Av. Luigi Rosiello, 891, ap. 6, Monte Alegre

14051-090, Ribeirão Preto, SP

Email: willyalvarenga@hotmail.com
Received: 29.11.2013

Approved: 28.07.2014 